ARQGA/1135

\title{
BRAIN METASTASIS
} OF HEPATOCELLULAR CARCINOMA DETECTED AFTER LIVER TRANSPLANTATION

\author{
Alex Vianey Callado FRANÇA, Ana MARTINELLI and Orlando Castro e SILVA Jr.
}

ABSTRACT - Aim - We report the case of a patient with hepatocellular carcinoma submitted to liver transplantation, who subsequently manifested tumor recurrence initially as brain metastasis. Case description - A 48-year-old male cirrhotic patient with hepatitis C infection, and two focal hepatic lesions, had a cytologic and histologic diagnosis of hepatocellular carcinoma. Before transplant, he was submitted to adjuvant treatment with a combination of arterial embolization and intratumoral ethanol injection. In the $3^{\text {rd }}$ month post-liver transplantation, the patient developed headache, nausea and vomiting, without any neurological impairment. Brain computed tomography and magnetic resonance imaging identified an expansive hypervascular lesion with internal bleeding. Evaluation of the surgical explant revealed macroscopic invasion of portal vessels. Conclusion - Brain metastasis of a hepatocellular carcinoma after liver transplantation may occur. This metastasis may have occurred before or soon after the transplant. Patients with hepatocellular carcinoma, awaiting liver transplant, should be screened for cerebral metastasis. Vascular invasion may indicate hematogenic dissemination of the tumor.

HEADINGS - Carcinoma, hepatocellular. Brain neoplasms, secondary. Liver transplantation.

\section{INTRODUCTION}

Hepatocellular carcinoma (HCC) is the most frequent primary tumor of the liver. Cirrhosis of the liver is present in about $90 \%$ of patients with $\mathrm{HCC}$, being the most important risk factor for the development of this malignant neoplasia ${ }^{(1)}$. Diagnosis of the tumor in an early stage permits the institution of radical curative treatment, such as surgical resection, orthotopic liver transplantation (OLT) and percutaneous treatments. OLT represents a major therapeutic option for patients with small $\mathrm{HCC}^{(1,6)}$. Adjuvant treatment with arterial tumor embolization and/or percutaneous alcohol injection can help the patient by preventing tumor growth while waiting for a liver transplant ${ }^{(1,2,10)}$.

After the possibility of surgical resection is ruled out, OLT represents the major treatment option for cirrhotic patients with HCC. The rates of tumor recurrence are low, about $8 \%$, among selected patients with early tumors and no evidence of metastasis ${ }^{(6)}$. Relapses frequently occur after the first year of transplant, mainly involving the implanted liver, the lungs and the bones.

We report a case of a patient with cirrhosis of the liver due to hepatitis $\mathrm{C}$ virus, and $\mathrm{HCC}$, submitted to liver transplantation and in whom brain metastasis of the tumor was detected in the third postoperative month.

\section{CASE REPORT}

A 48-year-old male patient with cirrhosis of the liver due to hepatitis $\mathrm{C}$ virus presented two focal hepatic lesions with a cytologic and histologic diagnosis of hepatocellular carcinoma (Edmondson II). One lesion was $3.5 \mathrm{~cm}$ in diameter and located in the right hepatic lobe and the other $1 \mathrm{~cm}$ in diameter, was in the left hepatic lobe.

The patient was placed on a waiting list for OLT. While in list, he was submitted to adjuvant treatment by intratumoral ethanol injection into the smaller lesion with complete response [total tumor necrosis by computed tomography (CT)] and combined arterial embolization and intratumoral ethanol injection of the larger lesion with partial response (tumor necrosis more than 50\%). After 7 months of evolution, an additional lesion measuring about $3 \mathrm{~cm}$ in diameter appeared in a right lobe and was also treated by combined arterial embolization and intratumoral ethanol injection. $\mathrm{CT}$ of the chest and abdomen as well as bone scintigraphy did not demonstrate the presence of distant metastases of the HCC.

One year and 2 months after being placed on the waiting list the patient was submitted to OLT by the piggyback technique. At that time, serum alpha-fetoprotein concentration was 15,000 $\mathrm{ng} / \mathrm{mL}$. The patient was submitted to a double immunosuppression scheme with cyclosporin and corticosteroids.

In the second postoperative month, an increase in hepatic enzyme levels was observed and the patient was submitted to a liver biopsy, with a diagnosis of ductopenic rejection. At that time, the immunosuppression scheme was converted, with cyclosporin being replaced by tacrolimus, with improvement of enzyme levels.

In the third postoperative month, the patient developed headache, nausea and vomiting, with no focal neurological deficit. CT and nuclear magnetic resonance of the brain identified an expansive hypervascular lesion with internal bleeding in the

Liver Transplant Group, Medical School of Ribeirão Preto, University of São Paulo, São Paulo, SP, Brazil.

Address for correspondence: Dr. Alex Vianey Callado França - Divisão de Gastroenterologia - Departamento de Clínica Médica, FMRP-USP - Av. Bandeirantes, 3900 - Monte Alegre - 14048-900 - Ribeirão Preto, SP, Brazil. E-mail: avcfranca@hcrp.fmrp.usp.br 
left occipital region compatible with a neoplastic lesion (Figures 1,2). The patient was submitted to symptomatic treatment, with progressive improvement of headache. Serum alpha-fetoprotein level was 30,000 $\mathrm{ng} / \mathrm{mL}$. Chest and abdominal tomography, as well as bone scintigraphy, were performed. Among these techniques, abdominal CT revealed several nodular images in the liver compatible with tumor recurrence, 1 week after presenting the neurological picture. Aspirative cytology confirmed the presence of HCC in the implanted liver.

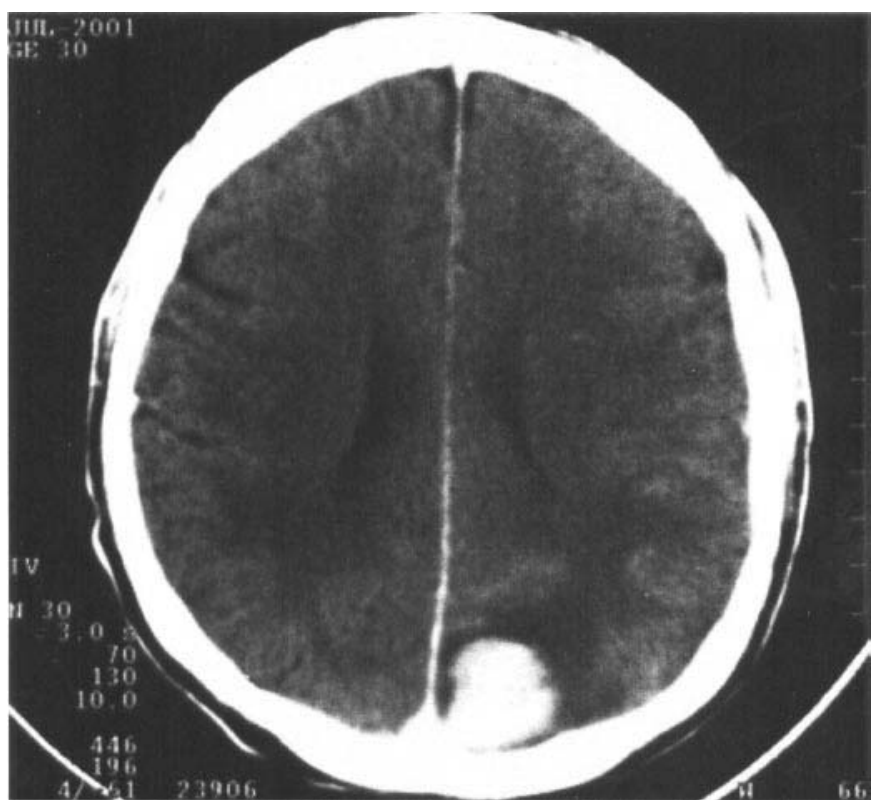

FIGURE 1 - Contrast-enhanced CT scan of the brain demonstrating a high-density area in the left occipital region

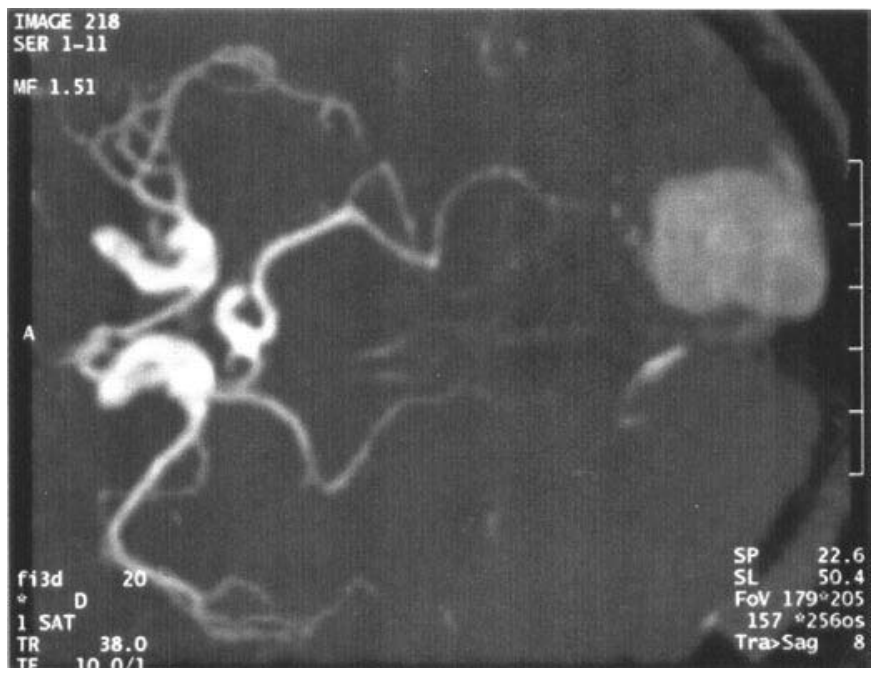

FIGURE 2 - Nuclear magnetic resonance of the brain demonstrating a hypervascular expansive lesion in a left occipital region

The patient was followed-up clinically without specific tumor treatment and died 5 months after OLT due to tumor progression.

Histological examination of the explanted liver revealed the presence of macroscopic tumor invasion of peritumoral and the hepatic hilar vessels.

\section{DISCUSSION}

OLT is one of the major treatments for patients with HCC. OLT is indicated for patients with small single tumors up to $5 \mathrm{~cm}$ in size or with up to three nodules none of which exceeds $3 \mathrm{~cm}$, with survival similar to that of tumor-free patients submitted to liver transplantation ${ }^{(1,6)}$.

Hepatocellular carcinoma metastatizes mainly to the lungs, bones and the adrenal glands. Cerebral metastasis is a rare occurrence, with few case reports in the literature ${ }^{(7,9)}$. In this patient, the metastasis may have occurred before the transplant, which could explain the early manifestation after the procedure. The immunosupression may have contributed to the increased tumoral growth rate.

Post-OLT tumor recurrence is related to some characteristics of the tumor. Nodule size, when larger than $5 \mathrm{~cm}$, is related to a higher probability of neoplastic recurrence. The presence of vascular invasion, especially of the portal system, is one of the major factors related to relapse ${ }^{(3)}$. However, since this invasion usually occurs in small vessels, the imaging methods applied before OLT are unable to identify this vascular microinvasion by the tumor. Tumor differentiation and pre-OLT serum alpha-fetoprotein levels also seem to be related to postoperative recurrence ${ }^{(1)}$. Our patient had an HCC with three nodules, one of them $3.5 \mathrm{~cm}$ in size, with absence of vascular invasion as determined by imaging methods. After transplantation, macroscopic invasion of the portal vessels by the tumor was observed. The tumor was moderately differentiated (Edmondson II) and serum alpha-fetoprotein level, at the time of OLT, was $15,000 \mathrm{ng} / \mathrm{mL}$. All of these factors are considered to represent a risk for tumor recurrence before and during the postoperative period. However, recurrence was identified early after surgery (3 months), while it is frequently observed 1 year after OLT.

The use of pre-transplant adjuvant therapy has been discussed in the literature ${ }^{(2,10)}$. Because of the long time of permanence on the waiting list for a transplant, more than 12 months in Brazil, the patient may loose the perspective of a transplant due to tumor growth, since the mean time for HCC duplication is 6 months $^{(1)}$. This is the reason why adjuvant therapy is suggested before OLT. Most groups adopt arterial embolization of the tumor ${ }^{(10)}$. Combined therapy by intratumoral ethanol injection and arterial embolization was adopted in order to induce greater tumor necrosis, a result that was observed in the present case. However, as previously reported in the literature, percutaneous treatment of HCC may cause pulmonary metastasis ${ }^{(4)}$ and release mRNA for alpha-fetoprotein in the peripheral circulation ${ }^{(5)}$. Although the clinical relevance of this fact has not been confirmed, the release of mRNA for AFP may represent the major possibility of hematogenic dissemination of tumor cells.

Post-transplant tumor recurrence is observed in about $8 \%$ of cases, with frequent relapses in the implanted liver, in the bones, the adrenal glands and the lungs. Cerebral metastasis before OLT is rare ${ }^{(4,5)}$. This is the first report of a brain metastasis of HCC after a liver transplant.

The clinical presentation with headache and nausea without a neurological deficit may be attributed to the use of immunosuppressive medication. However, we suggest that transplanted patients with HCC should be investigated for the presence of brain metastases after the onset of any neurological signals, with or without a motor deficit. We believe that tomographic evaluation of the brain should be stimulated before OLT in patients with HCC inspite of the rare occurrence of brain metastases, mainly in those patients on the waiting list for a long time. This is justified 
by the major nature of the surgical procedure and by the increased neoplastic proliferation occurring after immunosuppression.

In the present report we discuss the presence of HCC metastasis in the brain after liver transplantation and the possibility of its occurrence before the procedure. Screening for cerebral metastasis in patients with HCC awaiting transplant, was also commented on. The advanced stage of the tumor with invasion of portal vessels and the adjuvant pre-OLT therapy may be related to the tumor dissemination observed in this patient. Like other authors ${ }^{(8)}$, we believe that, due to the risk of tumor dissemination, the possibility of living donor liver transplantation should be discussed for patients with early HCC when the time on the waiting list for OLT is more than 6 months, thus eliminating the need for adjuvant antitumoral procedures.

França AVC, Martinelli A, Silva Jr OC. Metástase cerebral de carcinoma hepatocelular após transplante de fígado. Arq Gastroenterol 2004;41(3):199-201.

RESUMO - Objetivo - Relatar o caso de paciente com carcinoma hepatocelular submetido a transplante de fígado, que subseqüentemente manifestou recurrência tumoral em cérebro após o transplante. Descrição do caso - Homem de 48 anos de idade, com cirrose hepática secundária à infecção pelo vírus da hepatite C, com duas lesões focais hepáticas diagnosticadas como carcinoma hepatocelular pela citologia e histologia. Antes do transplante, foi submetido a tratamento coadjuvante com embolização da artéria hepática e injeção intra-tumoral de etanol. No terceiro mês pós-transplante, o paciente apresentou cefaléia, náuseas e vômitos, sem déficit neurológico focal. Tomografia computadorizada e ressonância magnética de crânio identificaram lesão expansiva hipervascular com sangramento interno. Avaliação da peça cirúrgica do transplante de fígado evidenciou invasão tumoral macroscópica da veia porta. Conclusão - A metástase cerebral de carcinoma hepatocelular após transplante de fígado pode ocorrer antes ou logo após a cirurgia. Pacientes, em lista para transplante de fígado, devem ser investigados para presença de metástase cerebral. Invasão vascular pode indicar disseminação tumoral hematogênica.

DESCRITORES - Carcinoma hepatocelular. Neoplasias cerebrais, secundárias. Transplante de fígado.

\section{REFERENCES}

1. Bruix J, Sherman M, Llovet JM, Beaugrand M, Lencioni R, Burroughs AK, Christensen E, Pagliaro L, Colombo M, Rodés J for the EASL Panel of Experts on HCC. Clinical management of hepatocellular carcinoma. Conclusions of the Barcelona-2000 EASL conference. European Association for the Study of the Liver. J Hepatol 2001;35:421-30.

2. Groupe D'Etude et de Traitement du Carcinoma Hépatocellulaire. A comparison of lipiodol chemoembolization and conservative treatment for unresectable hepatocellular carcinoma. N Engl J Med 1995;332:1256-61.

3. Kirimlioglu H, Dvorchick I, Ruppert K, Finkelstein S, Marsh JW, Iwatsuki S, Bonham A, Carr B, Nalesnik M, Michapoulos G, Starzl T, Fung J, Demetrius A. Hepatocellular carcinomas in native livers from patients treated with orthotopic liver transplantation: biologic and therapeutic implications. Hepatology 2001;34:502-10.

4. Liou TC, Shih SC, Kao CR, Chou SY, Lin SC Wang HY. Pulmonary metastasis of hepatocellular carcinoma with transarterial chemoembolization. J Hepatol 1995;23:563-8.

5. Louha M, Poussin K, Ganne N, Zylberberg H, Nalpas B, Nicolet J, Capron F, Soubrane O, Vons S, Beaugrand M, Berthelot P, Franco D, Trinchet JC, Brechot C, Paterlini P. Spontaneous and iatrogenic spreading of liver-derived cells into peripheral blood of patients with primary liver cancer. Hepatology 1997;26:998-1005.
6. Mazzaferro V, Regalia E, Doci R, Andreola S, Pulvirenti A, Bozzetti F, Montalto F, Ammatuna M, Morabito A, Gennari L. Liver transplantation for the treatment of small hepatocellular carcinoma in patients with cirrhosis. N Engl J Med 1996;334:693-9.

7. Peres MF, Forones NM, Malheiros SM, Ferraz HB, Stavale JN, Gabbai AA. Hemorrhagic cerebral metastasis as a first manifestation of a hepatocellular carcinoma. Case report. Arq Neuropsiquiatr 1998;56:658-60.

8. Sarasin FP, Majno PE, Llovet JM, Bruix J, Mentha G, Hadengue A. Living donor liver transplantation for early hepatocellular carcinoma: a life-expectancy and costeffectiveness perspective. Hepatology 2001;33:1073-9.

9. Tanabe H, Kondo A, Kinuta Y, Matsuura N, Hasegawa K, Chin M, Saiki M. Unusual presentation of brain metastasis from hepatocellular carcinoma. Two case reports. Neurol Med Chir 1994;34:748-53.

10. Venook AP, Ferrell LD, Roberts JP, Emond J, Frye JW, Ring E, Ascher NL, Lake JR. Liver transplantation for hepatocellular carcinoma: results with preoperative chemoembolization. Liver Transpl Surg 1995;1:242-8. 